\title{
FATHOM
}

\section{Some Thoughts on... Far from the Madding Crowd and its Adaptations}

Quelques réflexions sur... Far from the Madding Crowd et ses adaptations

\section{Laurence Estanove}

\section{(2) OpenEdition}

\section{Journals}

\section{Electronic version}

URL: http://journals.openedition.org/fathom/592

DOI: $10.4000 /$ fathom.592

ISSN: 2270-6798

\section{Publisher}

Association française sur les études sur Thomas Hardy

\section{Electronic reference}

Laurence Estanove, "Some Thoughts on... Far from the Madding Crowd and its Adaptations ", FATHOM [Online], 3 | 2016, Online since 30 April 2016, connection on 20 April 2019. URL : http:// journals.openedition.org/fathom/592; DOI : 10.4000/fathom.592 


\title{
Some Thoughts on... Far from the Madding Crowd and its Adaptations
}

Quelques réflexions sur... Far from the Madding Crowd et ses adaptations

\author{
Laurence Estanove
}

\section{Introduction: “Bringing Shepherd Back"}

1 In the whole of Hardy's work, Far from the Madding Crowd is probably, today, the novel that has entailed the most numerous adaptations, or at least adaptations of the most various kinds. The multiplication of those in very recent years may naturally be said to testify to the modernity of Hardy's writing. But one might also wonder what attracted a variety of artistic practices in that particular novel of Hardy's, while others, such as Tess, have enjoyed a greater popularity yet generated a more restricted number of adaptations. To this day, four filmmakers as well as one cartoonist and one opera composer have made Hardy's fourth novel their own. Between John Schlesinger's 1967 film, starring Julie Christie and Terence Stamp, and Thomas Vinterberg's own 2015 version, Nicholas Renton's 1998 TV adaptation provided a 216-minute truthful transposition of Hardy's novel, while Posy Simmonds's 2008 graphic novel Tamara Drew and its subsequent transposition to the cinema by Stephen Frears in 2010 offered a modern-day interpretation of a much more fanciful nature ${ }^{1}$. To such media one should add another adaptation, more uncommon and of a less popular form in the present cultural industry: the opera written by British composer Andrew Downes and first presented at the 2006 Thomas Hardy Conference and Festival in Dorchester².

2 A simple Internet search may also disclose other adaptations of a far more amateur kind, such as the Gryphon Film Production made by students of the Dorset Comprehensive Gryphon School, a full-length feature film shot entirely on location in Dorset and featuring a cast of students aged 11 to 18. Presented at the Hardy Conference and Festival in Dorchester last summer, it was described as "a tale of Love, Romance and Tragedy" (BBC News). One may also stumble upon a spoof TV show, "Weatherbury's Got Talent", featuring Frank Troy, Farmer Boldwood and Bathsheba as judges of contestants in a Pop 
Idol style show, as well as a short musical by a group of teenagers, "part of an English class joke gone seriously wrong", filmed in what appears like a back garden and based on a Justin Timberlake song - "Bringing Sexy Back" having turned into "Bringing Shepherd Back"...

Leaving the joke aside, this short survey clearly indicates how of Hardy's novels, Far from the Madding Crowd appears to be one of the most well-known among young people in Britain, most obviously due to the simple fact that it is often chosen as part of the literature curriculum at school. That particular Hardy novel is indeed easily accessible to all readers, not being as violent and gloomy as the later and most famous ones, but just as representative of the author's writing. What the trivial examples mentioned above also tell us is how diverse the responses to reading Far from the Madding Crowd can be - from tragic romance to ludicrous pastoral sexiness. I would argue that it is such generic and tonal instability that accounts for the diversity of the adaptations, Hardy's own evasiveness allowing for a wide range of artistic possibilities.

The perception of Hardy's novel by the artists who chose to adapt it is itself relevant. It is indeed particularly telling that two of the artists I have mentioned chose Hardy and Far from the Madding Crowd for completely opposite reasons. Andrew Downes thus explained why he and his wife Cynthia, the librettist for the opera based on the novel, chose Far from the Madding Crowd over other Hardy novels (Tess and Jude): "After a lot of thought, Cynthia and I decided that Far from the Madding Crowd would suit us best in terms of operatic adaptation. We both like happy endings" (Downes). Conversely, cartoonist Posy Simmonds described her interest in Hardy by stating: "I do like his moralism and his gloomy endings" (Wroe).

5 So how to reconcile happy and gloomy endings? Such contrasted readings reveal how, originally in Hardy's novel, tones and genres intermingle - how tragedy is often relieved by humour or the grotesque, and how, conversely, comedy is never to the full, always tainted. I have chosen to focus here on some aspects that are particularly relevant in that respect: the treatment of pastoralism, the transposition of scenes of pure tragedy such as the fate of Fanny Robin, and how the various versions manage the blending of tones and genres so perfectly balanced in Hardy's novel.

Little mention will be made here of the central character of Bathsheba. Naturally, much could be said of what interpretations may lie in her impersonation by sixties pop icon Julie Andrews or by today's celebrity magazine faves Carey Mulligan and Gemma Arterton. Because it precisely stands as the central unchangeable element in all adaptations, her character might tend to attract all attention and to eclipse others, the array and complexity of which are nonetheless typically Hardy's. One cannot strip the latter's novel down to the single plotline of Bathsheba's personal story. From the little I have so far been able to reflect on, it seems to me that this might be where Vinterberg's film has fallen through to some extent, failing to retain the vivifying complexity of intertwining plotlines and individual destinies, of contrasting codes from various artistic genres. These, however, are mere impressions garnered from a single viewing of that latest adaptation of Hardy's novel. For that reason, I have chosen not to include the 2015 film in my examination of the various adaptations, the present essay having been written for the most part several years before the film's release. I am thus leaving it for the prospective reader and viewer to reflect on how the following considerations may resonate with the work of director Vinterberg and his screenwriter David Nicholls. 


\section{The backcloth of pastoralism}

7 Unsurprisingly, pastoralism runs through all adaptations. It naturally serves as backcloth to the story, providing the various versions with obvious motifs of rural life and the sense of a genuine connection with the country's past and traditions. In the opera, the pastoral setting and rural folklore are indeed given primal importance, appearing at the onset of the adaptation. The opera was staged in St Mary's Church in Dorchester and filmed, then edited later on for DVD distribution - a process whereby opening credits were added, featuring a series of carefully selected paintings of rural life by wildlife artist Gordon Beningfield (1936-1998), author of Hardy Country (1983) and Hardy Landscape (1990) ${ }^{3}$, thus explicitly setting the scene in a pastoral context. The music itself was intended as a reflection of that context: "The modality of the folk music likely to have been played in Dorset during the time in which the novel is set has been fully taken into account", Andrew Downes's website tells us (Downes ${ }^{4}$ ). The vividness of the setting is made complete as repeatedly in the opera, for scenes such as the sheep shearing or harvest suppers, the characters engage in folk-dancing down the church's main aisle, thus ensuring that the church space is entirely redefined as that of a Wessex rural community of the mid $19^{\text {th }}$ century.

The films also rely on the presentation of an authentic rural microcosm, both in the exposition of the setting with long shots over the Dorset countryside, and in details and individual scenes of local life and folklore - scenes of field or farm work, of cattle grazing, of community gatherings at the local inn or the Malthouse. Genuine "rustics" - or, to use Gabriel Oak/Andy Cobb's words from Frears's film, "expert yokels" - are also always there to serve as pastoral backdrop. In Hardy's novel, pastoralism is itself often associated with the story's comic overtones. The scene at the Malthouse is a good example of that connection between humour and pastoralism, particularly well preserved in Renton's TV version which features a much more even-tempered maltster than in Hardy's text. The scene as a whole is a case in point of warmth, simplicity and friendliness, one of several scenes in Renton's version which truly present the rustics - especially the older ones - in an endearing light, as simple but true, humane and wise figures.

\section{Tragic traits}

9 At the other end of the spectrum, pure tragedy is also manifest in most adaptations, and actually more present than comedy and pastoralism. Fanny Robin is certainly the character that retains an untainted sense of tragedy across all adaptations - though to a much lesser extent, it seems, in Vinterberg's which gives her little presence on screen. Her relationship with Troy, certainly because it is not directly represented in the novel, is diversely treated. It appears as tender in the first two films (in Schlesinger's Troy has that movement of patting her on the head as you would a child or a dog) while in the opera, Troy appears as essentially lustful and violent: tenor Simon Walton's voice switches from singing to speaking or actually shouting, and his character even slaps Fanny onstage for keeping him waiting and "fooling" him at the church.

10 Fanny already appears as a martyr in Hardy's novel, and this is made obvious in most adaptations, to various degrees: it is visually conveyed in the films, for example in the way she appears on her last walk along Casterbridge highway in Renton's version, the 
Virgin-like sanctity of her figure being made obvious as a direct illustration of Hardy's last description of her on her knees, "in a bowed attitude, her face upon her bosom" (Hardy 1986, 207). In the opera, her saintly nature is made visible again in the credits of the DVD version where each character is presented with a symbolic or metonymic image: Bathsheba is featured with a mirror, Troy with the shoulder sleeve insignia of a red soldier's coat; but Fanny's is the most moving and the one which creates a direct connection with the setting of the production, since it is religious image, a stained glass featuring a saint. In Schlesinger's film, she is given a full scene for her final walk, which is made to look even more as a way of the cross since it is a painful ascent, and the presence of the dog that the people from the workhouse will chase is retained, thus enhancing the sense of pathos. Conversely, the scene is entirely absent from Vinterberg's version.

Whatever degree of tragedy is given to her fate in the other versions, she fully carries that profound sense of pathos, eliciting compassion. This is rendered musically in the opera when news of her death reach Bathsheba with the counterpoint of voices between the latter, her maids and the rustics. Fanny seems to be given more prominence still in the 1967 and 1998 film versions as both actually stage her relationship with Troy even where it remains only hinted at in Hardy's novel. In Renton's version she is also given extra scenes, reinforcing the sense of a self-sacrificial figure: we see her at her lodgings before the aborted wedding, then, after she is dismissed by Troy, searching for work and doing the hard tasks of a servant or farm labourer. She tells the other servants how she was engaged to a soldier, blaming herself for the marriage's failure which was, in her own words, "for the best".

In the modern version of Tamara Drew Fanny is transposed - fairly clearly, I would say into Jody, the bored teenage fan of rock drummer Ben Sergeant, Troy's present-day incarnation. Even in as frivolous an adaptation as Posy Simmonds's version may appear, Fanny/Jody does originally suffer a tragic fate: in the graphic novel, she dies by inhaling computer cleaner after celebrating her encounter with her idol Ben. Her death is a key part of the story, as it is after all the death of a teenager, a local tragedy that raises concern among parents and appears in dramatic fashion in the local press (Simmonds ${ }^{5}$ ). As we know, the censorship which acted originally on Hardy's novel mostly concerned the case of Fanny, and it still seems to be so if we consider the way her transposition into Jody evades seduction or unwanted pregnancy, and even, in the very last step of the chain of popular circulation that Frears's own adaptation of Simmonds's work constitutes, how she is made to survive and achieve her dream: the film's end credits thus feature the song "Jail-Bait Jody", a direct address of pop star Ben to his devoted fan.

In Far from the Madding Crowd moments of pure tragedy also concern other characters, of course: the loss of Gabriel's sheep, for example, appears in scenes of climactic intensity in Schlesinger's and Renton's films, as signalled by the quickening of rhythm and the poignant score. The tragic intensity of that episode is also rendered in the opera by entrusting the scene solely to the orchestra in the first of only two interludes, simply entitled "Gabriel's fate - depicted by the orchestra". Gabriel later recounts his fate to the rustics at the maltster's, and thus, unlike the secretive figure we are presented with in Hardy's novel, he clearly entails compassion and appears hence as a pitiful character. In Tamara Drew, in a far lighter tone, Gabriel's incarnation Andy Cobb had a graphic design business and lost it, consequently presenting himself as a loser (Simmonds) - a "pedigree loser" (Frears). 
14 As for Boldwood, I would argue that in the adaptations the tragedy carried by his character is rather associated with a form of social deviance and of psychological imbalance. The social deviance is manifest in the way his obsession cuts him off from reality and makes him lose his self-respect, as evoked in the novel: "Now the people sneer at me - the very hills and sky seem to laugh at me till I blush shamefully for my folly. I have lost my respect, my good name, my standing - lost it, never to get it again" (Hardy 1986, 159-160). In Renton's version for example, Boldwood's pathological obsessiveness is signalled by the presence of a harrowing piano motif, while the loss of his self-respect and social consciousness appears through scenes and details of private or public humiliation, such as the throwing away of his money into the river.

In Tamara Drew, Boldwood's double Nicholas Hardiman is a successful writer of detective stories cheating on his wife with the young and glamorous Tamara/Bathsheba in what appears as a fairly typical example of a present-day midlife crisis plotline. During a press conference at a literary festival, he announces his intention to kill his character, a professional suicide that occurs just as his obsession with Tamara is at its highest. Right after that sensational public announcement he learns that Tamara is leaving him and appears utterly shattered by the news, to the point of mental imbalance. Yet in the film, his fit of insanity appears as grotesque, as he tears to pieces the book a fan is handing for signature, then hands it back thankfully, with a sign of relief - a scene most obviously intended to make the audience laugh. The transposition of Boldwood into Nicholas Hardiman offers a good illustration of the comical and satirical colouring taken on by Hardy's original story in Tamara Drewe where, for example, the playful yet fateful Valentine is turned into an obscene email. In Simmonds's graphic novel, despite such comic overtones, we do sense in Hardiman's character the tragic potential destiny of a deranged mind, reaching its apex in his fateful death at the hooves of mad cattle. As many critics have noted, however, Frears's Tamara Drew is much lighter than Simmonds's. Frears's film presents itself and was unquestionably advertised as a comedy. This is probably why Hardiman's death might not appear as horrendous in the film version as originally intended in the graphic novel. Indeed, one may note that Simmonds was actually surprised to see that the audience at Cannes where the film premiered were laughing at the sight of a man crushed to death by cattle (Merigeau).

\section{The balance of tragicomedy}

16 The humour of that modern-day version of Hardy's novel appears in some grotesque scenes involving details of rural life - another illustration of the story's elemental pastoralism. For instance, the first physical contact between Bathsheba/Tamara and Gabriel/Andy is no longer a matter of life and death where the former saves the latter, but has a grotesque if not bawdy character, involving Tamara wiping raw eggs off Andy's shirt with a handful of straw. The comic quality of Frears's Tamara Drewe also relies on a fair amount of witticism and erudite references, many of which actually conjure up Hardy himself, both as author and man. Simmonds's graphic novel has an important additional character with the American academic Glen working at the writers' retreat set up by Nicholas Hardiman's wife Beth. In Frears's film, Glen's fellow literary retreaters are named Diggory, Eustacia and Tess, and he is preparing a book on Hardy, while in Simmonds's graphic novel his concern is with Verlaine. Such blatant acknowledgement of the story's roots (need one even mention the name of Hardiman?) did not feature in the 
graphic novel, which worked at barely disclosing the references. Director Frears and screenwriter Moira Buffini chose to explicitly include Hardy in the frame, even visually so (Glen has adorned the wall of his attic room with a portrait of Hardy) and to interlace Simmonds's plot even further with Hardy's life and work: Glen thus tells Beth, the betrayed wife of Nicholas, about the plot of The Well-Beloved in which a man falls in love successively with a woman, her daughter, and granddaughter, and he even mentions the fantastical theory of Hardy's syphilitic condition professed in the TLS by Dr Frizzell in 2006, to much academic outcry (Frizzell).

An important device that relays the balance between the comic and tragic while creating dramatic tension is the amount of spying, overhearing and gossip. This is a central feature of Hardy's novel and of his writing more generally, and it is duly transposed in the various adaptations, yet again in a more markedly humorous way in Tamara Drewe which provides several examples of comic relief via scenes of spying and gossiping. The most striking is certainly the film scene that offers the parallel editing of Beth and Nicholas arguing on the one hand and of the writers gossiping at the dinner table on the other, while Glen is overhearing the argument from the toilet, thus combining the tragedy of betrayal and separation with the grotesque of a purely farcical situation.

The opera also offers the medium to transpose Hardy's own ability to switch from the comical to the tragic, as the same group of singers, maids and men, can be heard in turns as humorous gossips and tragic chorus. That balance is thus either expressed through counterpointing or through discordance - both of which allow for the blending of tones. This is particularly tangible in the opera, since music does ideally lend itself to that type of blending. It is made clear from the very opening: the prelude exposes the opera's main themes and motifs through the combined presence of romance (strings), tragedy (woodwind, brass, percussions), with occasional strokes of pastoral comedy (piccolo or glockenspiel). Full discordance appears in the opera but also in Renton's film where it is particularly marked during Boldwood's Christmas party, serving to sustain both the sense of his insanity and the threat of Troy's return. In that scene, not only is the music discordant but so is the dancing, visibly awkward and uncoordinated.

\section{“Change and chancefulness", order and discordance}

19 Music similarly carries a sense of unease in Schlesinger's version, most strikingly so when Fanny goes to the wrong church and finds herself waiting in vain as a military band is rehearsing. The irony of the situation is manifest as her presence disrupts the musicians who start playing out of tune. In that particular adaptation, the sense of discordance is actually carried to an extremity of decadence and decay. The film's pastoralism is rather that of an end-of-era bleakness, as testified by the opening which sharply contrasts with the overall warm atmosphere of Renton's version, for example. After the scene of the fire, where the latter features a moment of warmth and community sharing at the Malthouse, Schlesinger's skips that episode and continues directly with the scene when Bathsheba as new mistress pays her employees - a scene that conjures more unease than pastoral comedy as the representation of those "rustics" is rather an exhibition of dull-wittedness and degeneracy than an endearing portrait of rural life. The pastoral grotesque featured in Schlesinger's version has an awkward, threatening face, the face of a gargoyle ${ }^{6}$. 

ending tone of each adaptation is also particularly relevant in that respect. Despite the concluding marriage of hero and heroine, Hardy's novel does end on the subdued happiness and uncertain sense of order underlined by Bathsheba's smiling rather than laughing and by Joseph Poorgrass's statement that "it might have been worse" (Hardy 1986, 308). The opera, on the one hand, openly signals the return to order and harmony with an explicit celebration of happiness. The return to order is also expressed by restoring the church space's consecrated function of wedding celebration, after having been the arena of pagan dancing and fierce arguments. A similar atmosphere of harmonious pastoralism comes to conclude Renton's version. In Schlesinger's film, however, the harmony of the wedding is markedly tainted by the presence of the village choir and band singing and playing out of tune. The sense that no real order is restored is further confirmed by the last shot of the film where the music box, a gift from the late Troy to his wife, serves as an ominous presence in the midst of Bathsheba and Gabriel's newly wed life.

What seems to remain constant throughout all adaptations might precisely be a sense of uncertainty, of unease or elusiveness - a combination of transience and ineluctability, of "change and chancefulness" as put by Hardy himself in one of his earliest poems, "The Temporary the All" (Hardy 2001, 7). That tension is exemplified by Gabriel's dog, particularly in Schlesinger's and Renton's films: his foolishness and unpredictability is signalled from the beginning, an element of uncontrollable but necessary disruption that will cause tragedy. A similar function is given in Tamara Drewe to the ominous presence of Troy/Ben's own dog that will be the cause of Nick Hardiman's death by stampede. As a counterpoint, we might see permanence embodied in the constant presence of the rustics, acting as chorus, and of course in the level-headed reliable figure of Gabriel. In his spare time, Tamara Drewe's Andy smokes marijuana - we are told that "he just seems happy being alone, green and composty, watching stuff grow" (Simmonds). But such characters of constancy and the pastoral setting they are part of are themselves also threatened by change and modernity. In Tamara Drewe, the threat is signalled by the arrival in the country town of Ewedown of academics and urbanites whom Andy calls "outsiders" and "rich bastards" (Simmonds).

The threat of modernity is indeed a central feature in Hardy's writing; it might be even more so in later novels, but it is already present in Far from the Madding Crowd, and all adaptations seem to have made it their own, to some degree. One may remember how Polanski's Tess had depicted that menace with the flashing devilish red of the new threshing machine. In Tamara Drewe a similar visual disruption comes to signal the threat to the old order of rural life as the allure of Troy's red coat is transposed into the yellow Porsche of Ben. The disruption from modernity is also aural with the disturbing presence of Tamara's house alarm or Ben's loud car stereo. There is also an indie rock festival taking place in the area and which the teenagers themselves complain about ${ }^{7}$.

The tension between order and discordance, old and new, the rural and the urban, is one thing which links all versions of Far from the Madding Crowd and directly echoes Hardy's writing. As the late poet Mick Imlah in his praise of Simmonds's Tamara Drewe put it, "[t]here is nothing in Hardy [...] which more grimly conveys the paralysis of lesser rural life than [Simmonds's] pictures of Casey and Jody at the old bus shelter. Andy Cobb laments that Ewedown now has 'no shop, no bus, no post office', but it is the teenage population who have to act out the consequences" (Wroe). The characters of these bored 
teenagers are indeed much more in tune with Hardy's writing than would first appear. Precisely because of their boredom, their obsession with stars and fame, they paint a true-to-life picture of teenage life today, especially in rural communities ${ }^{8}$. Jody is a case in point of teen risk behaviour, involved in petty crime (trespassing on private property), alcohol and drug taking, and family difficulties. Her behaviour might be seen as exemplifying a certain topicality, a modern unease also conveyed by the character of Nicholas Hardiman with his typically modern midlife crisis. Adapted, one needs to remember, from the two tragic figures of Far from the Madding Crowd, both characters express a general sense of boredom and pointlessness.

\section{Conclusion: the matrix}

It seems apt, to briefly conclude on these thoughts, to turn to Glen, the academic - and, in Frears's film, the Hardy specialist. His first appearance shows him in his attic room working on his book. He is writing the following: "This matrix is what Hardy meant by "ache of modernism" - a sentence he immediately dismisses as "crap". Scientifically speaking it might well be, but the use of that one famous expression from Tess might after all shed light on what, beyond the pastoralism and tragicomedy, constitutes the timelessness of Hardy's early novel. Its adaptations thus confirm that Far from the Madding Crowd was indeed already about that ache of modernism, which the rest of Hardy's work would come to examine more openly.

\section{BIBLIOGRAPHY}

BBC News, "School Makes Hardy Feature Film", 2 July 2009, news.bbc.co.uk/2/hi/uk_news/ england/dorset/8129928.stm (last accessed 26 Mar 2016).

Beningfield, Gordon, Hardy Country, New York: Viking, 1983.

Beningfield, Gordon, Hardy Landscapes, New York: Viking, 1990.

Downes, Andrew, personal website, www.andrewdownes.com/Opera.html (last accessed 26 Mar 2016).

Frizzell, Robert Alan, “Corroded Life: Emma Lavinia Hardy, 1840-1912: A Retrospective Diagnosis of Syphilis", The Times Literary Supplement 5410 (2006): 12-13.

Hardy, Thomas, Far from the Madding Crowd, ed. Robert C. Schweik, London \& New York: Norton, 1986.

Hardy, Thomas, The Complete Poems, ed. James Gibson, Basingstoke: Palgrave, 2001.

Merigeau, Pascal, “La ferme littérature de Posy Simmonds”, L'Obs, 13 July 2010, bibliobs.nouvelobs.com/bd/20100713.BIB5451/la-ferme-litterature-de-posy-simmonds.html (last accessed 26 Mar 2016). 
Wroe, Nicholas, “A Life in Drawing: Posy Simmonds”, The Guardian, 28 August 2010, www.theguardian.com/culture/2010/aug/28/posy-simmonds-tamara-drewe-interview (last accessed 26 Mar 2016).

\section{NOTES}

1. Simmonds's Tamara Drewe appeared in 110 weekly instalments in the Guardian from September 17, 2005 to October 20, 2007. The story was subsequently published in full-length form as a graphic novel. Interviewed in The Guardian in 2010, Posy Simmonds later explained: "From Hardy I nicked six main characters and some bits of the plot." "For a long time into the series I only got one or two letters picking up on the links," she says, "but the clues were there." For one, as The Guardian notes, "[t]he classified ad that opens chapter one openly describes the writers' retreat as being 'far from the madding crowd'." (Wroe)

2. The opera had originally been commissioned by the Thomas Hardy Society and it premiered at St. Mary's Church, Dorchester in July 2006.

3. I am extremely grateful to Andrew Downes for his help in clarifying this and for his overall support of the present essay.

4. The composer's website having been amended lately, the quote no longer appears there. It can still be found at www.amazon.com/Far-From-Madding-Crowd-Andrew/dp/B0018DB39A (last accessed 26 Mar 2016).

5. Unfortunately, the pages of the edition of Simmonds's Tamara Drewe used for this essay are not numbered.

6. It seems also no accident that the film's atmosphere should have had that disturbing quality if one considers that its cinematography was entrusted to one Nicholas Roeg. At that moment in his career, Roeg had just worked with François Truffaut on the adaptation of Ray Bradbury's dystopia Fahrenheit 451 (1966) - incidentally also starring Julie Christie -; he would later come to direct such outlandish films as Performance (1970) and The Man Who Fell to Earth (1976), among others.

7. I am tempted to think of another Hardy connection there, as many festivals, such as the indie folk/rock End of the Road Festival, are held every summer at the Larmer Tree Gardens in Dorset, where in September 1895 Thomas Hardy had met Agnes Grove whom he would later celebrate on her death with the poem "Concerning Agnes" (Winter Words, 1928; Hardy 2001, 878).

8. “[D]ans les petits villages d'Angleterre, elle a repéré ces adolescentes qui passent le plus clair de leur existence à s'ennuyer à mourir sous l'auvent des arrêts de bus, elle a capté leur langage de charretier, saisi leurs rêves les plus insensés, pas plus délirants que ceux des apprentis écrivains." (Merigeau)

\section{ABSTRACTS}

In the whole of Hardy's work, Far from the Madding Crowd is probably to this day the novel having entailed the most numerous and varied adaptations. This essay seeks to offer some thoughts on the way several filmmakers as well as one opera composer and one cartoonist have made Hardy's work their own. The multiplication of adaptations in very recent years naturally testifies to the 
modernity of Hardy's writing. But one might also wonder what appealed to a variety of artistic practices in that particular novel of Hardy's. This essay looks at fundamental features of Hardy's novel - its pastoralism and blending of the tragic and the comical - and examines how such distinctive features have been transposed in cinematographic, operatic and graphic modes.

Dans l'ensemble de l'œuvre de Hardy, Far from the Madding Crowd est très certainement le roman qui a donné lieu au plus grand nombre d'adaptations, de nature également très variée. On cherchera ici à réfléchir à la façon dont plusieurs cinéastes mais également un compositeur d'opéra et une dessinatrice se sont approprié le roman de Hardy. La multiplication des adaptations ces dernières années témoigne naturellement de la modernité qui caractérise l'écriture de Hardy. Mais on peut également s'interroger sur ce qui a pu orienter l'intérêt de différentes pratiques artistiques actuelles vers cette œuvre en particulier. Cet article s'intéresse aux traits qui constituent les fondements de ce roman de Hardy - notamment son pastoralisme et le mélange du tragique et du comique qui s'y opère - et observe la façon dont ces traits distinctifs se voient transposés par les modes cinématographique, opératique et graphique.

\section{INDEX}

Keywords: adaptation, film, cinema, opera, graphic novel, pastoralism, tragedy, comedy, genre Mots-clés: adaptation, film, cinéma, opéra, roman graphique, pastoralisme, tragédie, comédie, genre littéraire

\section{AUTHOR}

\section{LAURENCE ESTANOVE}

Dr Laurence Estanove is a University Language Teacher (professeur agrégé) at Université Paris Descartes and she holds a PhD in English Literature from the University of Toulouse, France. She is journal editor and webmaster for FATHOM and one of its founder members. Her PhD thesis was devoted to the study of disillusionment in Hardy's poetry and she has published on Hardy's verse as well as his fiction and other writings. In parallel, she also conducts research on contemporary popular music. 